\title{
A NEW INVERTEBRATE FROM THE PONTA GROSSA FORMATION (DEVONIAN), PARANÁ BASIN, BRAZIL
}

\author{
ARTUR CHAHUD (1) \& THOMAS R. FAIRCHILD (D) \\ Departamento de Geologia Sedimentar e Ambiental, Instituto de Geociências, Universidade \\ de São Paulo, Rua do Lago, 562, Cidade Universitária 05508-080, São Paulo, SP, Brazil. \\ arturchahud@yahoo.com,trfairch@usp.br
}

\begin{abstract}
Pontagrossia reticulata $\mathrm{n}$. gen. et $\mathrm{sp}$. is described from the Lower Devonian (Emsian) Ponta Grossa Formation, Paraná Basin. The species is based on morphological characteristics shared by three contiguous casts clearly representing a single species, if not the same individual. The shape and organization of the fossil resembles that in some sponges, but until diagnostic evidence of its affinities can be recognized in these specimens, the new taxon will be left in open nomenclature. Nevertheless, this fossil is unlike any other invertebrate, plant, or algal fossil already known from the Ponta Grossa Formation, and thus represents a novel addition to the diversified cold-water Devonian paleobiota of Brazil.
\end{abstract}

Keywords: taphonomy, taxonomy, Gondwana, marine, Malvinokaffric Realm.

\section{INTRODUCTION}

The Jaguariaíva Member of the Lower Devonian (Lange \& Petri, 1967) Ponta Grossa Formation of the Paraná Basin (Figure 1A) at Jaguariaíva, State of Paraná, Southern Brazil, is represented by a succession of predominantly medium to dark-gray silty shales, well known for abundant and varied invertebrate fossils, microfossils, early plants remains and ichnofossils (Clarke, 1913; Kozlowski, 1913; Morsch, 1986; Fernandes, 1996; Bolzon et al., 2002). Among the invertebrates are trilobites, bivalves, gastropods, echinoderms (including carpoids and crinoids), Tentaculitoidea, conularids and, especially, a wide variety of brachiopods. This and other similar paleofaunas in Argentina, Bolivia, Islas Malvinas, and South Africa belong to the Malvinokaffric Realm (or paleobiogeographic province) (Richter \& Richter, 1942) that occupied high-latitude cold waters along the southern and southwestern margin of Gondwana. The Ponta Grossa assemblage, however, exhibits marked endemism of coldwater forms that Melo (1988) interpreted as due to its proximity to the coldest parts of Gondwana.

We here describe casts of a small chalice-like fossil unlike any previously described Lower Devonian fossil in the Paraná Basin. It consists of three small, contiguous, incomplete internal casts preserved in siltstone, that share enough features to allow them to be interpreted as fragments of a single benthic invertebrate species (Figure 2). The specimen was collected in place in a moderately bioturbated succession of clayey-silty shale at least four meters thick near the top of the Jaguariaíva Member of the Ponta Grossa Formation on the NW side of state highway PR-092 between Jaguariaíva and Arapoti, Paraná (Figure 1B). This same interval yielded diverse fossils, some in place and others overturned or dislocated, mostly as molds and casts of bivalves, Tentaculitoidea, conularids, trilobites and at least four taxa of unbroken, solitary, and grouped brachiopods.

\section{SYSTEMATIC PALEONTOLOGY}

Pontagrossia gen. nov.

Material. Three contiguous to overlapping incomplete internal casts that represent basal and upper parts of a sessile benthic organism. The specimen is deposited under access number GP/1E-11425 in the Invertebrate Fossil Collection of the Laboratório de Paleontologia Sistemática (LPS) of the Instituto de Geociências of the Universidade de São Paulo (IGc-USP), São Paulo, Brazil.

Etymology. Pontagrossia, after the Formation name, Ponta Grossa.

Type species. Pontagrossia reticulata gen. et sp. nov. by monotypy.

Diagnosis. As for the type species.

Pontagrossia reticulata sp. nov.

(Figure 2)

Diagnosis. Chalice-like body with narrow, rounded base and divergent margins till less than mid-height of the chalice where they then become parallel. Upper margin flat to gently undulating. The chalice presents a reticulate pattern of column-like segments and transverse subtly rugose bands of varied breadth formed by the intersection of prominent narrow longitudinal grooves and more tenuous fine transverse striae and/or shallow grooves. Fine longitudinal striae are also present, most evident near the upper margin.

Type material. GP/1E-11425 (LPS, IGc-USP). Holotype, cast 1 (Figures 2A1, 2B); paratypes, cast 2 (Figures 2A2, 2C) and cast 3 (Figures 2A3, 2D). 

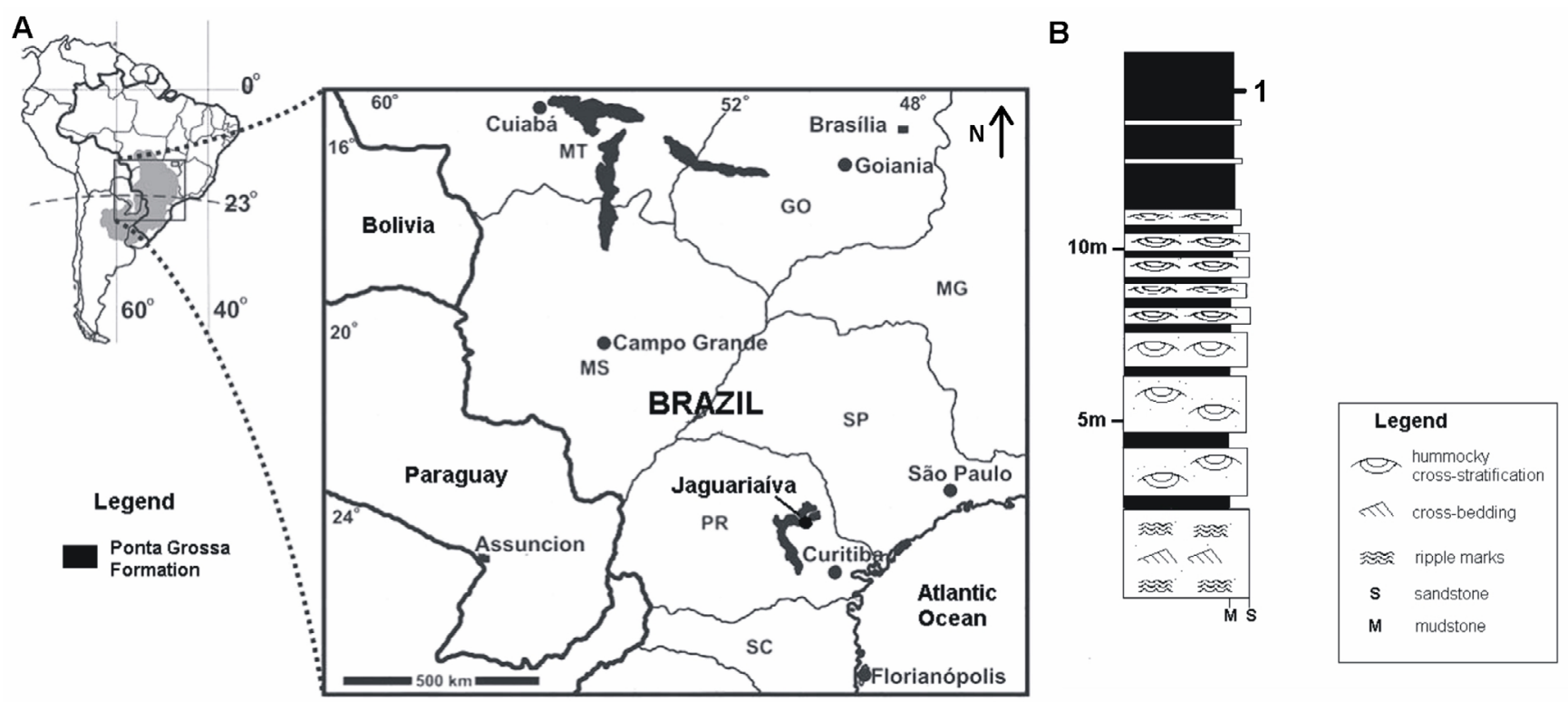

Figure 1. A, outcrop map of the Ponta Grossa Formation in the Paraná Basin (gray region in the map of South America) highlighting Jaguariaíva, Paraná, where the fossil was collected (after Scheffler \& Fernandes, 2007). B, Schematic section of the Ponta Grossa Formation as exposed on highway PR-092, Jaguariaíva, Paraná, Brazil (modified from Bergamaschi, 1999).

Etymology. Species name, reticulata, after the pattern on the face of the chalice.

Localization. Jaguariaíva Member, Ponta Grossa Formation. Road cut at NW side of state highway PR-092 between Jaguariaíva and Arapoti, State of Paraná, Brazil.

Description. The fossil consists of tree thin casts about $1 \mathrm{~mm}$ thick that represent the intact basal portion (cast 1) and two incomplete fragments of the upper portion (casts 2 and 3) of one or more specimens of Pontagrossia reticulata gen. et sp. nov. All three preserve in greater or lesser degree a reticulate pattern reflecting original aspects of body form and structure. Reticulation is formed by longitudinal and transverse elements, the former consisting of prominent grooves and/or fine striae and, at the upper margin, short terminal rods; and the latter comprising striae and/or thin shallow grooves. Together they define distinct columnar segments crossed by more tenuous, subtly rugose transverse bands of varied breadth, most evident in the largest, most complete cast (Figures 2A1 and 2B). This cast has a compressed chalice shape about 10 $\mathrm{mm}$ high with a rounded base and a slightly concave upper border, higher at one side, which appears to have been torn or broken. The original lateral margins are preserved and diverge rapidly upwards till just below mid-height, where they then become parallel, maintaining a width of about 9 $\mathrm{mm}$. Deep longitudinal grooves on the exposed face of the chalice define seven column-like features up to $12 \mathrm{~mm}$ long that extend for the entire height of the cast. Less-pronounced transverse grooves define a dozen or so bands generally less than $1 \mathrm{~mm}$ wide that give cast 1 a subtly rugose aspect. The intersection of columns and bands creates a reticulate pattern of small, faint rectangles and squares less than one square millimeter in area. The gently undulating original upper margin of $P$. reticulata gen. et sp. nov., evidently broken off in cast 1 , is preserved in casts 2 and 3 (paratypes). Both are roughly rectangular, cast 2 (Figures $2 \mathrm{~A} 2,2 \mathrm{C}$ ) measuring up to $8 \mathrm{~mm}$ in length and $5 \mathrm{~mm}$ in width, and cast 3 (Figures 2A3, 2D), $7 \mathrm{~mm}$ by $3.5 \mathrm{~mm}$. The lower left and lower right sides of cast 2 (Figure 2C) and the upper side of cast 3 (Figure 2D) are interpreted as original margins of the upper part of one or two individual specimens. In both paratypes dense fine longitudinal striae are more notable than in cast 1 . Fine short rods stand out along part of the upper margin of cast 3 . The reticulate pattern is present in these two casts but less distinct than in cast 1 , especially in clast 3 .

\section{TAPHONOMIC CONSIDERATIONS}

Obrution events were a major factor in preserving the abundant and diverse paleofauna of the Ponta Grossa Formation in the Jaguariaíva region (Rodrigues et al., 2003) and are invoked here to explain the preservation of Pontagrossia reticulata gen. et sp. nov.

The three parts of the fossil were molded by infilling of an internal cavity by the same fine sediment that encases them. The three fragments, although exhibiting partially broken or torn borders, are contiguous and still preserve basal, lateral, and terminal margins of the original body, suggesting both minimal transport and rapid burial, as are typical of obrution deposits.

Brachiopods and bivalve mollusks, also buried by obrution events, are common at the collecting site and are similarly found as molds, their calcareous shells having been leached away long after burial and lithification, a characteristic of the Ponta Grossa paleofauna observed throughout the Paraná Basin. Unlike the voids around these once shelly fossils, the space between the casts of Pontagrossia reticulata gen. et 

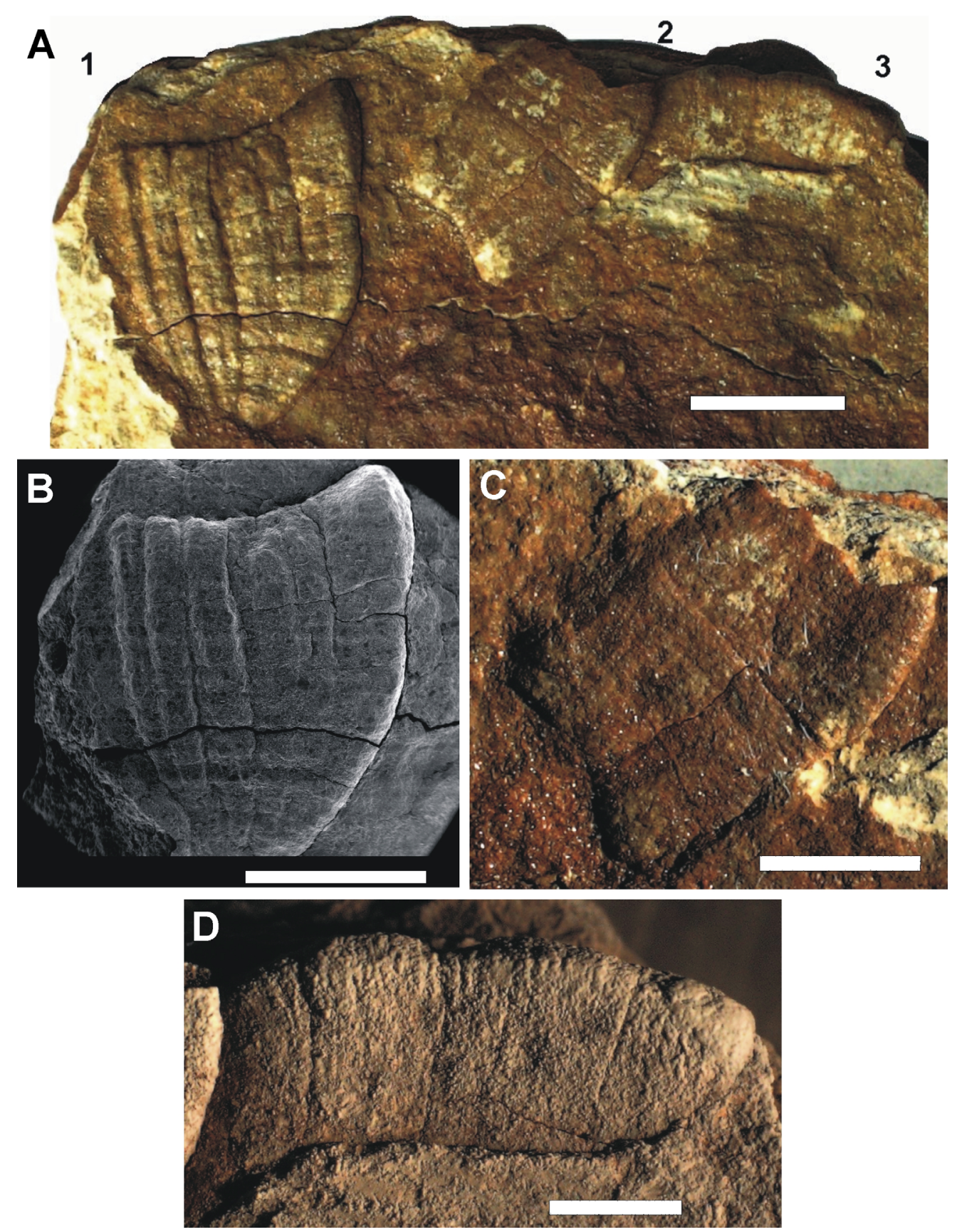

Figure 2. Pontagrossia reticulata gen. et sp. nov. of the Ponta Grossa Formation, Jaguariaíva, Paraná, Brazil. Specimen GP/1E-11425, consisting of three incomplete internal casts: A1, cast 1 (holotype), compressed chalice-like body with well-preserved base and lateral margins; A2-A3, casts 2 and 3 (paratypes); B, SEM image of chalice-like holotype (cast 1 of part A); C, cast 2 (paratype). Note fine striae running from upper left across faint transverse bands to lower right edge, the original upper body margin, where they become more pronounced. Uncoated specimen. D, cast 3 (paratype), showing at least four prominent longitudinal grooves and exhibiting distinct short rods along the gently undulating upper edge of the cast. Specimen coated with $\mathrm{Mg}$. Scale bars: $\mathrm{A}, \mathrm{B}=5$ $\mathrm{mm} ; \mathrm{C}=4 \mathrm{~mm} ; \mathrm{D}=2 \mathrm{~mm}$.

sp. nov. and the enclosing sediment is minimal. This and the laterally compressed form of the casts indicate that the body of the organism was neither heavily mineralized nor very thick, but rather compressible and putatively predominantly organic. We infer that it was open at the top with a deep central cavity and that it was through this opening that sediment filled a central cavity to produce the casts studied here. During compaction, original architectural features of the wall, like the gently undulating upper margin, the column-like longitudinal segmentation, and transverse banding, as well as arguably internal structural elements (fine striae and marginal rod-like features) were conserved, possibly with some superimposition upon the surface of the casts of both surficial and internal wall structures. The fine striae are problematic in that close inspection by light and electronic microscopy have not yet been able to clarify either their detailed morphology or reveal their original composition. They are, however, clearly restricted to the casts and not tectonic in nature (e.g. slatey cleavage). 


\section{DISCUSSION AND FINAL CONSIDERATIONS}

The three casts share enough features to group them as specimens of a single species. If they represent fragments of a single, cup-like individual, rather than branches of the chalice-like body or three different individuals, then their simplest reconstruction would be as an organism about 15 $\mathrm{mm}$ high with a narrow base and parallel sides about $10 \mathrm{~mm}$ across mid-section upward, flaring out slightly to about $15 \mathrm{~mm}$ at its upper margin. We infer that it was open at the top and attached to or embedded in soft sediment at its narrow base and, therefore, a sessile filter or suspension feeder. As such, it is a novel addition to the diverse Ponta Grossa paleobiota, different from all invertebrates, basal plants, algae, or other fossils already described from the formation.

The longitudinal segmentation and transverse banding defined by deep and shallow grooves, respectively, were prominent gross structural elements of the organism (cast 1). The much finer, parallel striae, particularly evident distally (cast 2), may represent biomineralized or, perhaps more likely, organic skeletal elements of the wall that were completely leached or degraded after casting.

The above characters, specifically the vase-like shape and reticulate pattern, invite comparison with Porifera. Indeed, Pontagrossia reticulata gen. et sp. nov. is similar in form to fossils of known articulated South American Paleozoic sponges (Carrera, 1994; Carrera \& Ortega, 2009; Carrera \& Rustán, 2015; Carrera et al., 2018; Mouro et al., 2014). However, P. reticulata gen. et sp. nov. does not have spicules, is smaller, less elongated, narrower at its base and less markedly reticulated than Paleozoic Porifera species (Botting, 2003, 2004; Botting \& Muir, 2018) and, therefore, classification in this phylum is uncertain.

\section{ACKNOWLEDGEMENTS}

The authors thank geologist T.A. Batista for help in the field and I.J. Sayeg for operating the SEM at the Instituto de Geociências, Universidade de São Paulo.

\section{REFERENCES}

Bergamaschi, S. 1999. Análise estratigráfica do Siluro-Devoniano (Formações Furnas e Ponta Grossa) da sub-bacia de Apucarana, Bacia do Paraná, Brasil. Instituto de Geociências, Universidade de São Paulo, PhD Thesis, 167 p.

Bolzon, R.T.; Azevedo, I. \& Assine, M.L. 2002. Sítio Jaguariaíva, PR: invertebrados devonianos de grande importância paleobiogeográfica. In: C. Schobbenhaus, D.A. Campos, E.T. Queiroz, M. Winge \& M.L.C. Berbert-Born (eds.) Sitios Geológicos e Paleontológicos do Brasil, Vol. 1, Departamento Nacional de Produção Mineral \& Serviço Geológico do Brasil, p. 33-37.

Botting, J.P. 2003. Growth patterns of Lower Palaeozoic sponges. Lethaia, 36:41-52. doi:10.1080/00241160310001263
Botting, J.P. 2004. An exceptional Caradoc sponge fauna from the Llanfawr Quarries, central Wales, and phylogenetic implications. Journal of Systematic Palaeontology, 2:31-63. doi:10.1017/S147720190300110X

Botting, J.P. \& Muir, L.A. 2018. Early sponge evolution: a review and phylogenetic framework. Palaeoworld, 27:1-29. doi:10.1016/j.palwor.2017.07.001

Carrera, M.G. 1994. An Ordovician sponge fauna from the San Juan Formation, Precordillera Basin, western Argentina. Neues Jahrbuch für Geologie und Paläontologie Abhandlungen, 191:201-220.

Carrera, M.G. \& Ortega, G. 2009. The hexactinellid sponge Cyathophycus from the Upper Ordovician of the Argentine Precordillera. Ameghiniana, 46:449-459.

Carrera, M.G. \& Rustán, J.J. 2015. The new genus Talacastospongia: insights on the first record of a Devonian sponge from South America. Journal of Paleontology, 89:912-919. doi:10.1017/ jpa.2016.9

Carrera, M.G.; Rustan, J.J.; Vaccari, N.E. \& Ezpeleta, M. 2018. A Mississippian hexactinellid sponge from Western Gondwana: taxonomic and paleobiogeographic implications. Acta Palaeontologica Polonica, 63:63-70. doi:10.4202/ app.00403.2017

Clarke, J.M. 1913. Fósseis Devonianos do Paraná. Vol. 1. Rio de Janeiro, Monographias do Serviço Geológico e Mineralógico do Brasil, 353 p.

Fernandes, A.C.S. 1996. Os Icnofósseis do Ordoviciano, Siluriano e Devoniano da Bacia do Paraná. Instituto de Geociências, Universidade Federal do Rio de Janeiro, PhD Thesis, 183 p.

Kozlowski, R. 1913. Fossiles dévoniens de l'état de Paraná (Brésil). Annales de Paléntologie, 8:105-123.

Lange, F.W. \& Petri, S. 1967. The Devonian of the Paraná Basin. Boletim Paranaense de Geociencias, 21/22:5-55.

Melo, J.H.G. 1988. The Malvinokaffric realm in the Devonian of Brazil. In: N.J. McMillan, A.F. Embry \& D.J. Glass (eds.) Devonian of the world, Vol. 14, Canadian Society of Petroleum Geologists, Memoirs, p. 669-704.

Morsch, S.M. 1986. Bivalves (Mollusca) da Formação Ponta Grossa (Bacia do Paraná - Devoniano). Revisão Sistemática. Anais da Academia Brasileira de Ciências, 58:403-431.

Mouro, L.D.; Fernandes, A.C.S.; Rogério, D.W. \& Fonseca, V.M. 2014. First articulated sponge from the Paleozoic of Brazil and a new organization of the Order Hemidiscosa. Journal of Paleontology, 88:171-178. doi:10.1666/12-108

Richter, R. \& Richter, E. 1942. Die Trilobiten der Weismes-Shichten am Hohen Venn, mit Bemerkungen über die Malvinocaffrische Provinz. Senckenbergian, 25:156-279.

Rodrigues, S.C.; Leme, J. \& Simões, M. 2003. Tafonomia comparada dos Conulatae (Cnidaria), Formação Ponta Grossa (Devoniano), Bacia do Paraná, Estado do Paraná. Revista Brasileira de Geociências, 33:381-390. doi:10.25249/03757536.2003334379388

Scheffler, S.M. \& Fernandes, A.C.S. 2007. Crinoidea da Formação Ponta Grossa (Devoniano, Bacia do Paraná), Brasil. Arquivos do Museu Nacional, 65:83-98.

Received in 05 May, 2019; accepted in 26 October, 2020. 